\title{
Variable retention forestry in European boreal forests in Russia
}

\author{
Ekaterina Shorohova ${ }^{1,2,3^{*}} \mathbb{D}$, Sergey Sinkevich ${ }^{1}$, Aleksandr Kryshen ${ }^{1}$ and Ilkka Vanha-Majamaa ${ }^{3}$
}

\begin{abstract}
We explored whether, and to what extent, variable retention (VR) forestry has been applied in European boreal forests in northwestern Russia. Our survey revealed VR since 1910. Between 1910 and the 1960s, the statistics showing how much was retained are largely missing. However, for example, in the 1950s, on a large scale in the Republic of Karelia, up to 200-ha-sized harvesting areas, 18-33\%, were retention patches with a mean growing stock of $30-40 \mathrm{~m}^{3} \mathrm{ha}^{-1}$. In the fellings defined as "incomplete clear fellings," which were the most common final felling type at that time, 11-40\% of the growing stock was left. Between the 1960s and the early 1990s, with more efficient harvesting and skidding techniques, conventional clear fellings with a much lower amount of retention were practiced. Concern about the regeneration of harvested areas gradually led to smaller (maximum $50 \mathrm{ha}$ ) harvesting areas and the increase of silvicultural activities. Until now, to ensure natural regeneration, patches of understory and 20-25 seed trees (i.e., ca. $15-25 \mathrm{~m}^{3}$ ) per ha have been left permanently in harvesting areas. Landscape-scale retention for protecting ecosystem functions and biodiversity was legislated in 1978 by preserving key biotopes up to 1000 ha in size. Since 2001, promoted by forest certification, the key biotopes, such as paludified forest patches, buffers around water bodies, and habitats of red-listed species, have also been retained in harvesting areas, together with a dispersed retention of different elements. Quantitative estimates of the amount of key biotopes are largely missing. However, estimates of $1-13 \%$ in harvesting areas and $23 \%$ in whole managed landscapes have been given. VR applied during the last century has emulated natural disturbances and created diverse uneven-aged forest structures with high amounts of diverse coarse woody debris. We conclude that an analysis of past and current retention practices is essential for estimating the global role of Russian forestry. Further decisions on the general direction of Russian forestry and, specifically, retention practices are important to address the global challenges of biodiversity loss and climate change.
\end{abstract}

Keywords: Biological legacies, Nature conservation, Biodiversity, Clear felling, Key biotopes, Coarse woody debris, Silviculture, Dispersed and aggregated retention

\section{Background}

The forests of the Russian Federation account for more than $20 \%$ of the planet's forest estate (The Russian 2012). They provide multiple ecosystem services, including timber production, biodiversity conservation, and climate change mitigation (Shvidenko et al. 2007; Gauthier et al. 2015; Lukina et al. 2015; Bukvareva and Zamolodchikov 2016). Thus, analyzing Russian forestry practices is essential for resolving global forest sustainability issues.

\footnotetext{
* Correspondence: shorohova@ES13334.spb.edu

${ }^{1}$ Forest Research Institute of the Karelian Research Centre of the Russian Academy of Sciences, Pushkinskaya str. 11, Petrozavodsk 185910, Russia ${ }^{2}$ Saint-Petersburg State Forest Technical University, Institutsky str. 5, Saint Petersburg 194021, Russia

Full list of author information is available at the end of the article
}

Variable retention (VR) forestry introduced in northwestern (NW) North America in recent decades to prevent the rapid ongoing degradation and simplification of forests and to address the need to better integrate wood production and biodiversity (Franklin 1989) has been widely adopted (Gustafsson et al. 2012; Lindermayer et al. 2012). Russian forestry has not yet been critically evaluated from perspectives of retention practices. In fact, even the concept of VR has not been discussed much in Russia. Here, we present an overview of the forest management treatments in NW Russian forests in the past and present that can be regarded as VR and discuss their global impact on biodiversity and ecosystem services. 
Finally, we speculate about future perspectives of retention forestry in Russia.

\section{NW Russian forests: a retrospective view}

\section{Forest resources and their use}

NW Russia represents a key area for satisfying rival forestry objectives containing economically important forest resources (Melnikov 2011), as well as the largest European boreal old-growth forests (Aksenov et al. 1999). Forests in NW Russia cover 53\% of the land area, of which the share of commercial forests is $62 \%$ (Federal 2019). Forests with restricted or totally forbidden forestry activities occupy 38\%. The dominant tree species are Norway spruce (Picea abies L., Karst.), Scots pine (Pinus sylvestris L.), birch (Betula pendula Roth. and B. pubescens Ehrh.), and aspen (Populus tremula L.) (Regional 2017, 2018).

In NW Russia, the history of significant human influence on forests has started in the fifteenth to sixteenth centuries, when forests were impacted by selective logging for firewood, production of tar, potash, and salt and later for large diameter trees to supply Peter the Great's shipbuilding (Dekatov 1961; Redko 1981; Fedorchuk et al. 2005; Sokolov 2006). Cuttings were made in winter time with a two-man cross-cut saw and a horse skidding. Slash and burn cultivation was widely applied in the beginning and in some places even until the middle of the twentieth century (Kozubov and Taskaev 2000; Fedorchuk et al. 2005; Sokolov 2006).

At the end of the nineteenth century, selective logging was concentrated around settlements and industrial centers (Kozubov and Taskaev 2000; Sokolov 2006). Large-scale, "concentrated" clear felling with harvesting areas of 50-100 ha in size and, in practice, even up to 1000 ha (Aksenov et al. 1999; Kozubov and Taskaev 2000;
Fedorchuk et al. 2005) was practiced after the Second World War (Sokolov 2006). Fellings had an unsystematic character, i.e., they were not properly planned either in size or in time (Fedorchuk et al. 2005; Sokolov 2006).

However, these clear-cuts were not conventional clearcuts, as large uncut tree patches (nedoruby in Russian) of different sizes were left (Solntsev 1950; Valentik 1950; Baranov 1954). Moreover, in the so-called incomplete clear fellings (uslovno-sploshnye rubki in Russian, Fig. 1), $61-90 \%$ of the stand growing stock was harvested (Melekhov 1966), which means a retention level of up to $40 \%$. From the 1910 s until the 1960s, these fellings were the most common felling types (Baranov 1954; Melekhov 1966). For example, $45 \%$ of the timber harvested in NW Russia, mainly in the Republic of Karelia, Komi Republic, as well as in the Vologda and Arkhangelsk regions in 1954, came from incomplete clear fellings (Baranov 1954). In "clear fellings" of that time, or actually retention fellings, more than $90 \%$ of growing stock was harvested, i.e., the retention level was up to $10 \%$ (Melekhov 1966).

Between the 1960s and the early 1990s, with more efficient harvesting and skidding techniques, practicing incomplete clear felling gradually ceased and was replaced by conventional clear felling. Concern of poor conifer regeneration and the increased share of deciduous forests (see Sokolov 2006, for literature review) progressively led to smaller (maximum 50 ha) harvesting areas. In the period between 2000 and 2013 in the FSC (Forest Stewardship Council)-certified NW Russian forests, the size of clear-cut areas varied from 7.6 to 25 ha with the mean value of 10 ha (Ilina and Rodionov 2017). Since the 1990s, selection felling has become more common. After 2000 in NW Russia, the share of selection felling varied across regions from 2 to $58 \%$ with the mean value of $22 \%$ (Annual 2012).

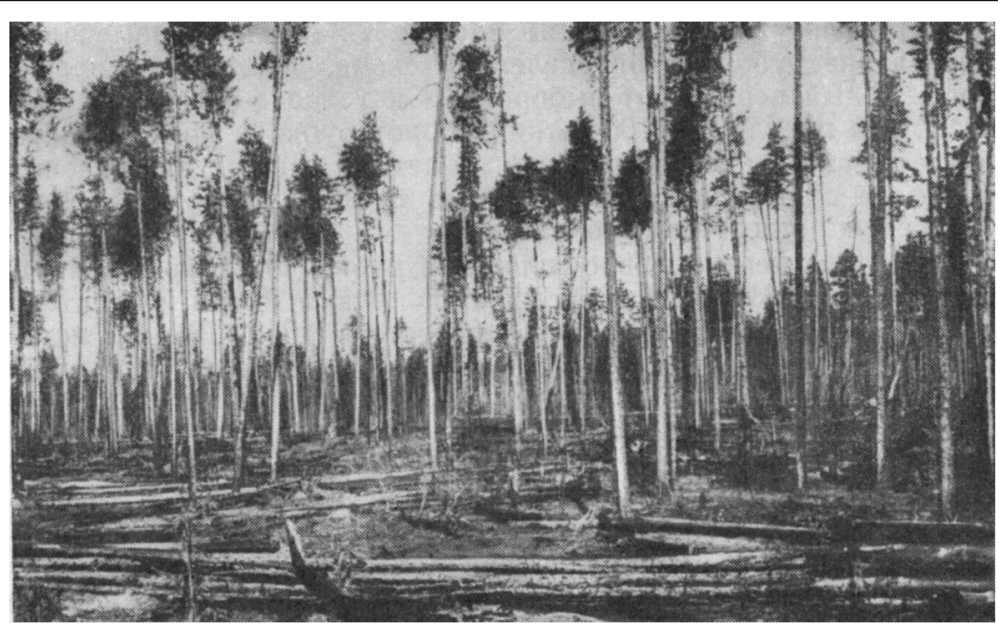

Fig. 1 The example of incomplete clear felling made in 1958 in a Scots pine-dominated forest in Arkhangelsk region with removal of 70\% of the growing stock. Photo: Vyacheslav Chertovskoj 
At present, the high share of deciduous forests in some regions (Fig. 2) and a lack of pre-mature forest stands in most regions (Fig. 3) influence future forestry. The mature and over-mature coniferous stands prevailing in the Komi Republic and Arkhangelsk and Murmansk regions (Fig. 3) are partly old-growth forests that have not ever been commercially harvested.

\section{Nature conservation: protected areas and special forest management categories}

There have been conservation efforts in Russia since the very beginning of forest use (eighth to twelfth centuries) (Teplyakov et al. 1998; Kobyakov et al. 2013; Kozlov 2017). In 1703, Peter the Great protected forests along rivers used for wood rafting (Redko 1981). In the 1890s, on a state level, all forests were divided into commercial and protective, i.e., protecting natural and cultural heritage (Kobyakov et al. 2013). The first strictly protected forest nature reserve (zapovednik in Russian) was established in 1917. In 2019, there are 103 strict nature reserves. Other protected areas include national parks, nature refuges, nature parks, and natural monuments (Sobolev et al. 1995; Gromtsev et al. 2018). In NW Russia, the share of strictly protected forests varies from 6 to $17 \%$ of the area of forest estate across the regions (Fig. 4).

Different functions of forests (protective, conservation, cultural, commercial) were acknowledged in national forest law in 1923 (Forest Code 1923) and formed the basis for classifications of forests into forest management categories (The Act 1943; Bajtin et al. 1974; Nikolayuk et al. 1977; National 2003; Forest Code 2007). At present, the first forest management category, where clear fellings are forbidden, consists of protective forests of special environmental, scientific, historical, or socio-cultural values. This category includes forests in protected areas, protective buffer zones along water bodies, shelterbelts by roads and railways, sites of high conservation value, urban forests, etc. In NW Russia, the share of protective forests in the forest estate is $38 \%$, varying from $15 \%$ in the Vologda region to $64 \%$ in the Murmansk region (Fig. 4). According to the Forest Code and Water Code, the width of forest buffers along water bodies can reach up to $3 \mathrm{~km}$

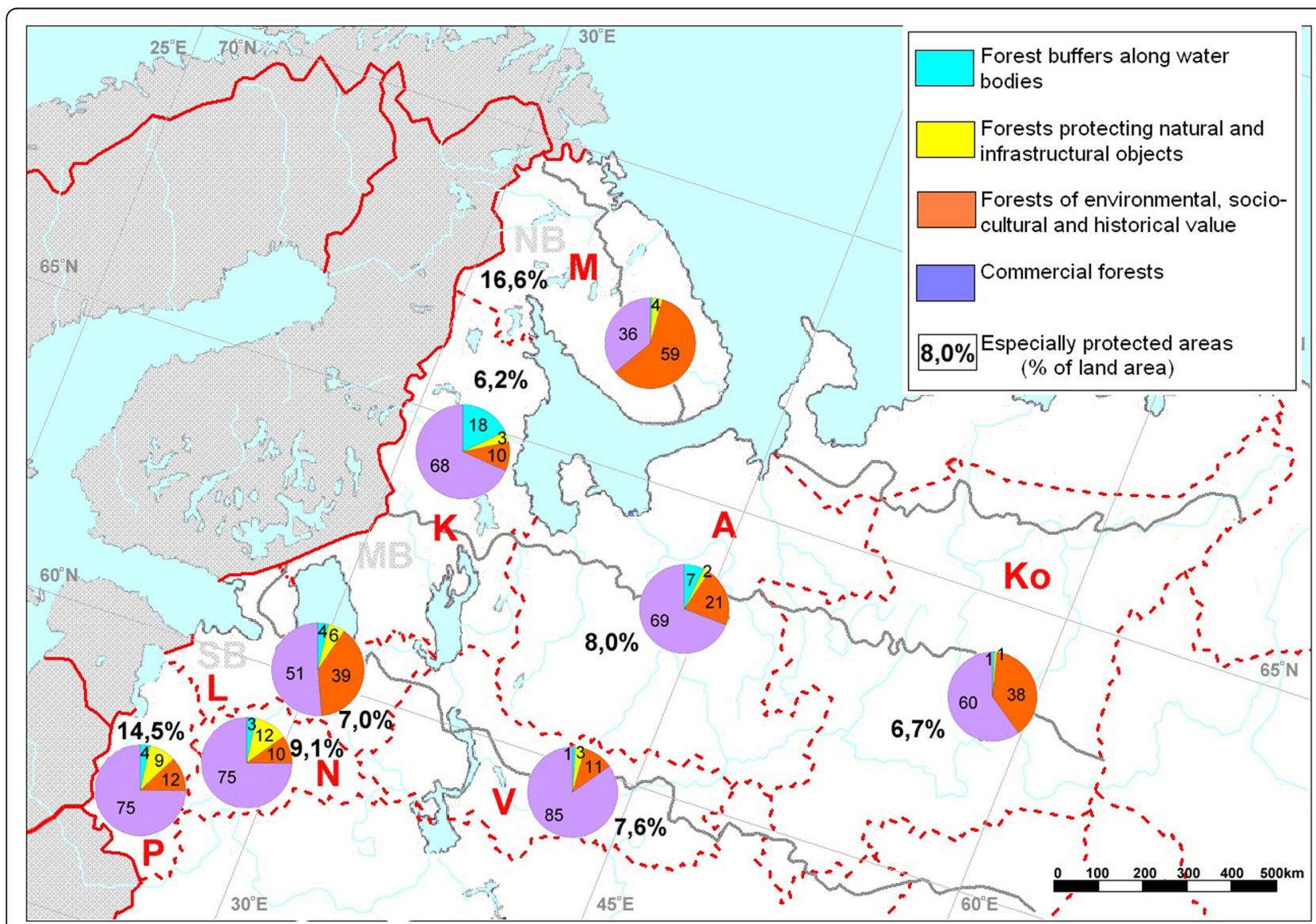

Fig. 2 Dominating tree species in different regions of NW Russia (Regional 2017, 2018). Red lines denote the borders between the countries. Gray lines denote the borders between vegetation zones (Bonh et al. 2000, 2003). NB northern boreal zone, MB middle boreal zone, SB southern boreal zone, HB hemiboreal zone. Dashed red lines denote the borders between the regions. A Arkhangelsk region, $\mathrm{K}$ the Republic of Karelia, Ko Komi Republic, L Leningrad region, M Murmansk region, N Novgorod region, P Pskov region, $V$ Vologda region 


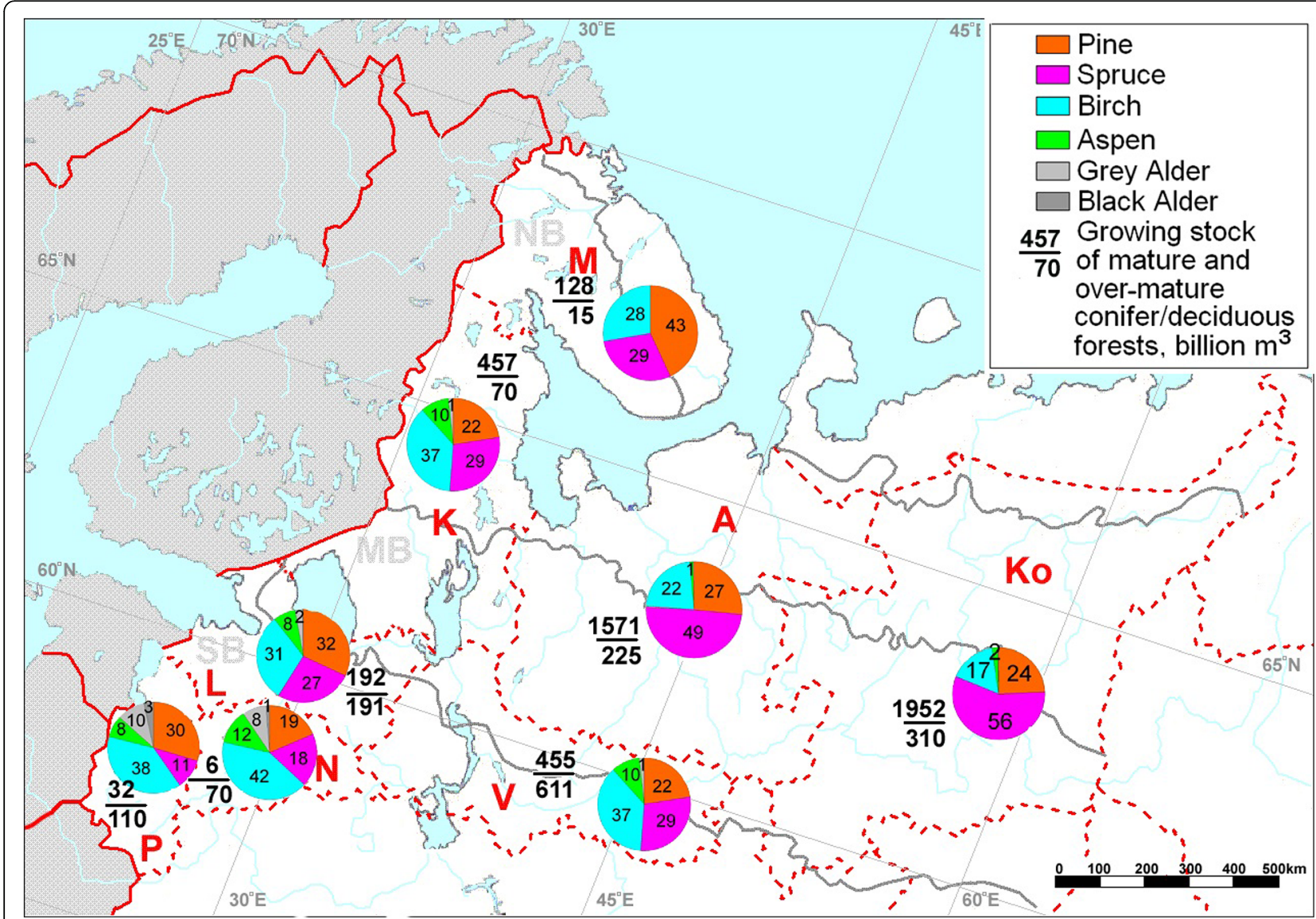

Fig. 3 Successional stages (age groups [gruppy vozrasta in Russian]) of forests in different regions of NW Russia (Regional 2017, 2018). Young - 0-40 (0-20) years for coniferous (deciduous) stands; mature-101-140 years and older for coniferous (deciduous) stands depending on vegetation zone, site index, and forest category; over-mature-all stands older than mature; pre-mature - 20 years before the age of maturity; middle-aged_all stands between young and pre-mature. The figures show the share of forests in each successional stage from total forested area. Red lines denote the borders between the countries. Gray lines denote the borders between vegetation zones (Bonh et al. 2000, 2003). NB northern boreal zone, MB middle boreal zone, SB southern boreal zone, HB hemiboreal zone. Dashed red lines denote the borders between the regions. A Arkhangelsk region, K the Republic of Karelia, Ko Komi Republic, L Leningrad region, M Murmansk region, N Novgorod region, P Pskov region, V Vologda region

(Leman et al. 2018). This sub-category of protective forests requires special attention in planning forestry activities (Ananyev and Sinkevich 2015), which is especially important to the Republic of Karelia, where the share of these forests $(18 \%)$ is the highest among the regions (Fig. 4). The majority of forest estate belongs to the second category and is used for commercial purposes (Fig. 4). The forests of the third category are "reserve" forests that are not planned to be harvested in the near (more than 20 years) future.

Protection of key biotopes (osobo zaschitnye uchastki in Russian) has started in 1978 on a state level and was legalized in forest management plans. The list of key biotopes has included, for example, forest buffers along small water bodies and ravines, forest edges, habitats of red-listed, endemic, and relict species and fragments (100-150 ha) of old-growth forests. The habitats of rare species and fragments of old-growth forests are completely excluded from harvesting. Clear felling is forbidden in all types of key biotopes.

Since 2001, the biodiversity conservation has been actively incorporated into forest management following forest certification criteria (Aksenov et al. 2000; Romanyuk et al. 2001; Yanitskaya, Shmatkov 2009; Yanitskaya 2010; Shmatkov 2013a, b) and promoted on a state level (Regulations 2016b).

\section{Silviculture}

The majority of forests in NW Russia has been developed through natural regeneration. The attributes of intensive forest management in, for example, neighboring Fennoscandian countries include clear felling with ten retention trees per ha (Vanha-Majamaa and Jalonen 2001; Gustafsson et al. 2012), followed by site 


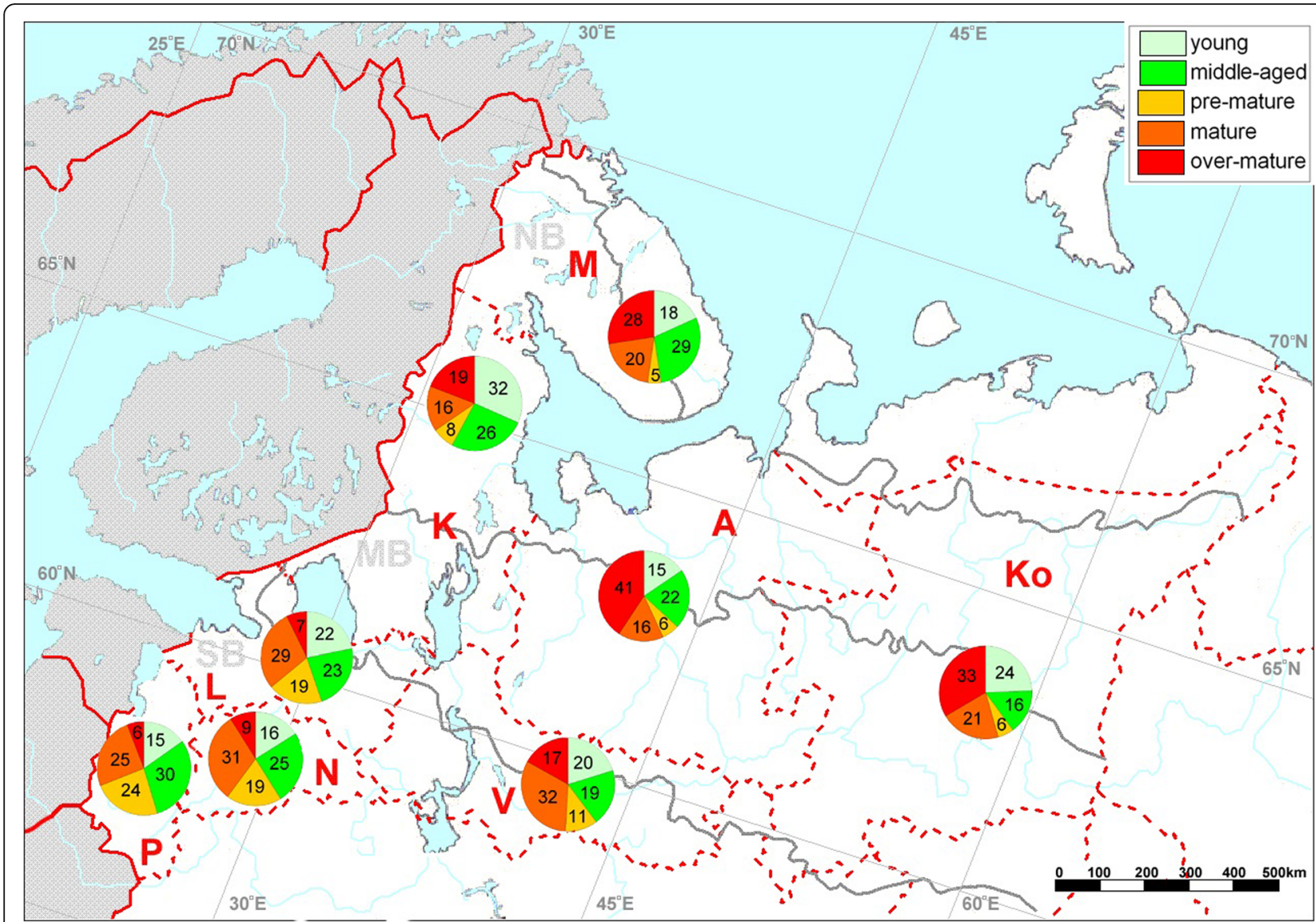

Fig. 4 The share of different forest management categories in different regions of NW Russia (Regional 2017, 2018). Red lines denote the borders between the states. Gray lines denote the borders between vegetation zones (Bonh et al. 2000, 2003). NB northern boreal zone, MB middle boreal zone, SB southern boreal zone, HB hemiboreal zone. Dashed red lines denote the borders between the regions. A Arkhangelsk region, K the Republic of Karelia, Ko Komi Republic, L Leningrad region, M Murmansk region, N Novgorod region, P Pskov region, V Vologda region

preparation, planting of trees, multiple thinnings during the rotation period, and final clear felling (Finnish 2018). In Russia, until now, these forestry treatments have been implemented in practice only sporadically (Knize and Romanjuk 2004; Sokolov 2006).

Since 1923, prescribed burning for the "clearing" of harvested areas and enhancing natural regeneration was used (Tkachenko 1931). For example, in the Republic of Karelia, it was done in ca. $8 \%$ of harvested areas (Davydov 1934). Later, it was replaced by partial burning (Sokolov 2006) and finally forbidden in 1993 to reduce fire risks. Currently, only logging slash piles are allowed to be burned. Since the 1940s, treatments ensuring successful forest regeneration a wiz: retaining seed trees, saving existing understory, sowing tree seeds, and lately, to some extent, planting have been applied in practice (Dekatov 1961; Kozubov and Taskaev 2000; Sokolov 2006). Soil preparation methods have been developed from manual to tractor scarifier or disk trencher and lately, but rather seldom, mounding has been applied. Until recently, however, the annual area of soil preparation has not exceeded 25\% of the regeneration area (Sokolov 2006). Planting was carried out manually earlier with seedlings with an open root system and later with partly mechanized planting of container-grown seedlings (Sokolov 2006). Nowadays, according to state-level regulations for forest regeneration (Regulations 2016a), methods of forest regeneration depend on the condition of the harvesting area (site conditions, the amount of viable seedlings, young and middle-aged trees, uncut patches, stumps, logs and logging slash, cover of grasses). In contrast to, for example, Finnish practice (Finnish 2018), where individual seed trees (20-100/ha) are later harvested after seedling establishment, in most cases in Russia, the 20-25 seed trees per ha are left permanently in the harvesting area so that the distance between the groups does not exceed $100 \mathrm{~m}$ (Regulations 2016b). The seed trees can potentially be cut during the first thinning (Regulations 2017). However, intermediate fellings in Russia are still rather rare (Tikhonov and Zyabchenko 1990; Chibisov et al. 2004), which leads to self-thinning and promotes additional coarse woody debris (CWD) inputs during forest 
succession. In Russia, stumps, tree tops, and other logging residues are typically left in harvesting areas (Ivanov et al. 2009), in contrast to, for example, Fennoscandia, where soil preparation and bioenergy removal have been widely practiced (Hautala et al. 2004; Rabinowitsch-Jokinen and Vanha-Majamaa 2010).

\section{Types and levels of retention}

Retained uncut forest patches and individual trees since the beginning of the twentieth century can be interpreted as variable retention forestry. Both aggregated and dispersed retention have been practiced (Figs. 1, 5, and 6) more or less in the same way as later in many other parts of the world (Scott et al. 2019). By volume, aggregates have dominated (Marjin 1957; Sakhovets 1977). Aggregates have been both island and edge aggregates (Figs. 1, 5, and 6). The large aggregated uncut forest patches were typically dominated by Norway spruce
(Marjin 1957; Sakhovets 1977) and located in paludified spots with a complicated stand structure and a lot of deadwood, i.e., the most valuable spots from a nature conservation perspective, and in other parts of Fennoscandia later suggested as woodland key habitats and optimal retention tree group sites (Vanha-Majamaa and Jalonen 2001; Lazdinis and Angelstam 2005; Timonen et al. 2010). Island aggregates have tended to be generally smaller than edge aggregates, which is especially important in maintaining connectivity between the unharvested areas, and thus biodiversity (Scott et al. 2019). Most dispersed retention trees have been mainly deciduous or low-diameter non-merchantable conifer trees (Tkachenko 1955). Since the 1930s, "silvicultural" retention has been represented by seed tree groups left in harvesting areas permanently (Fig. 7); young coniferous trees, as well as by large logging residues and CWD from previous forest stands (Sokolov 2006).

a

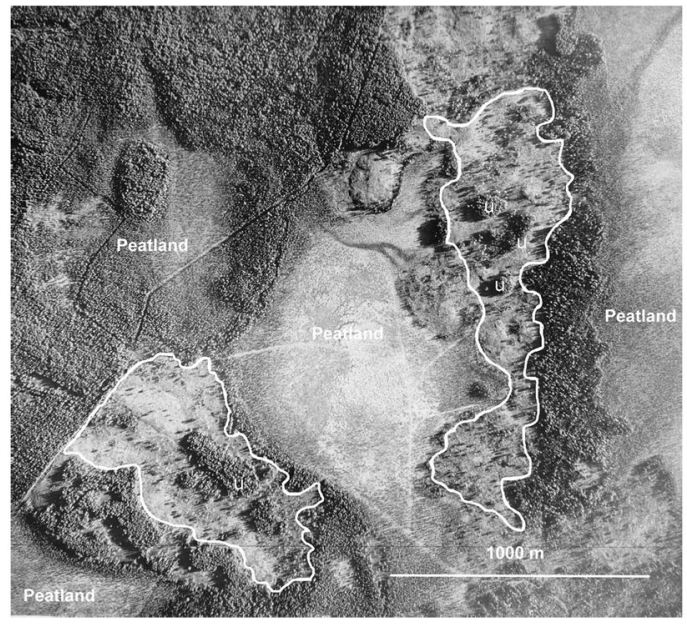

b

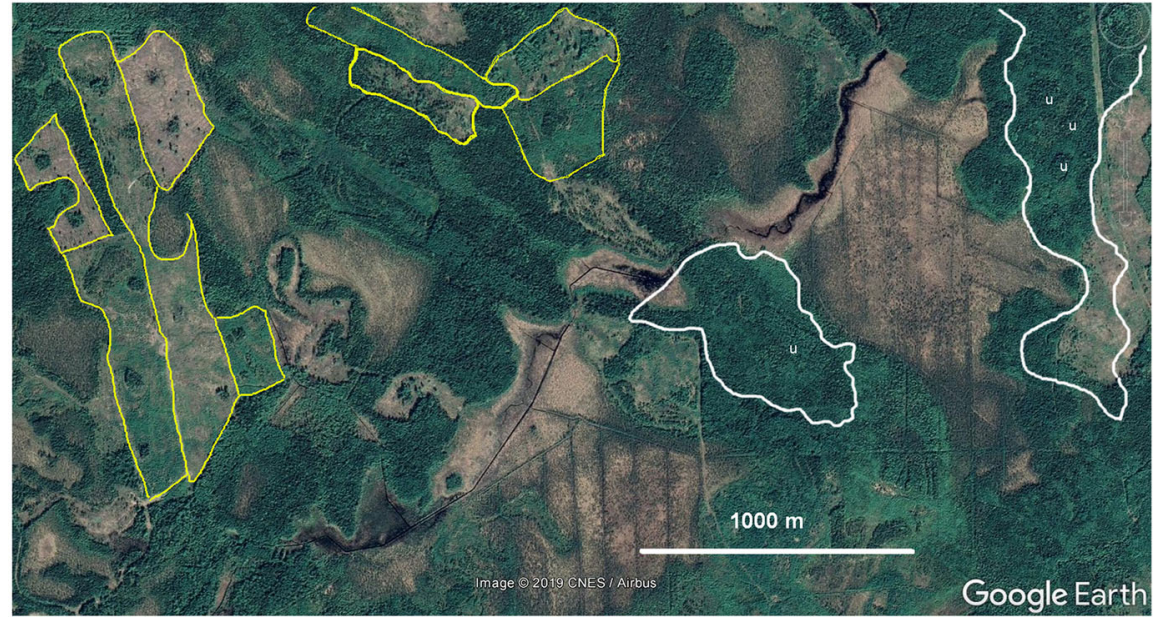

Fig. 5 a The examples of two clear-cuts with uncut patches made in 1969 in the middle boreal forest, $100 \mathrm{~km}$ to the west of Petrozavodsk, the Republic of Karelia on the aerial image taken in July 1969. b Forest succession after clear felling with uncut patches (u) made in 1969 (a) (white contours) and recent different aged clear-cut areas (yellow contours) with dispersed and aggregated retention on forest edges and in islands. The forested area also encompasses key biotopes and water buffer patches outside the harvesting area 

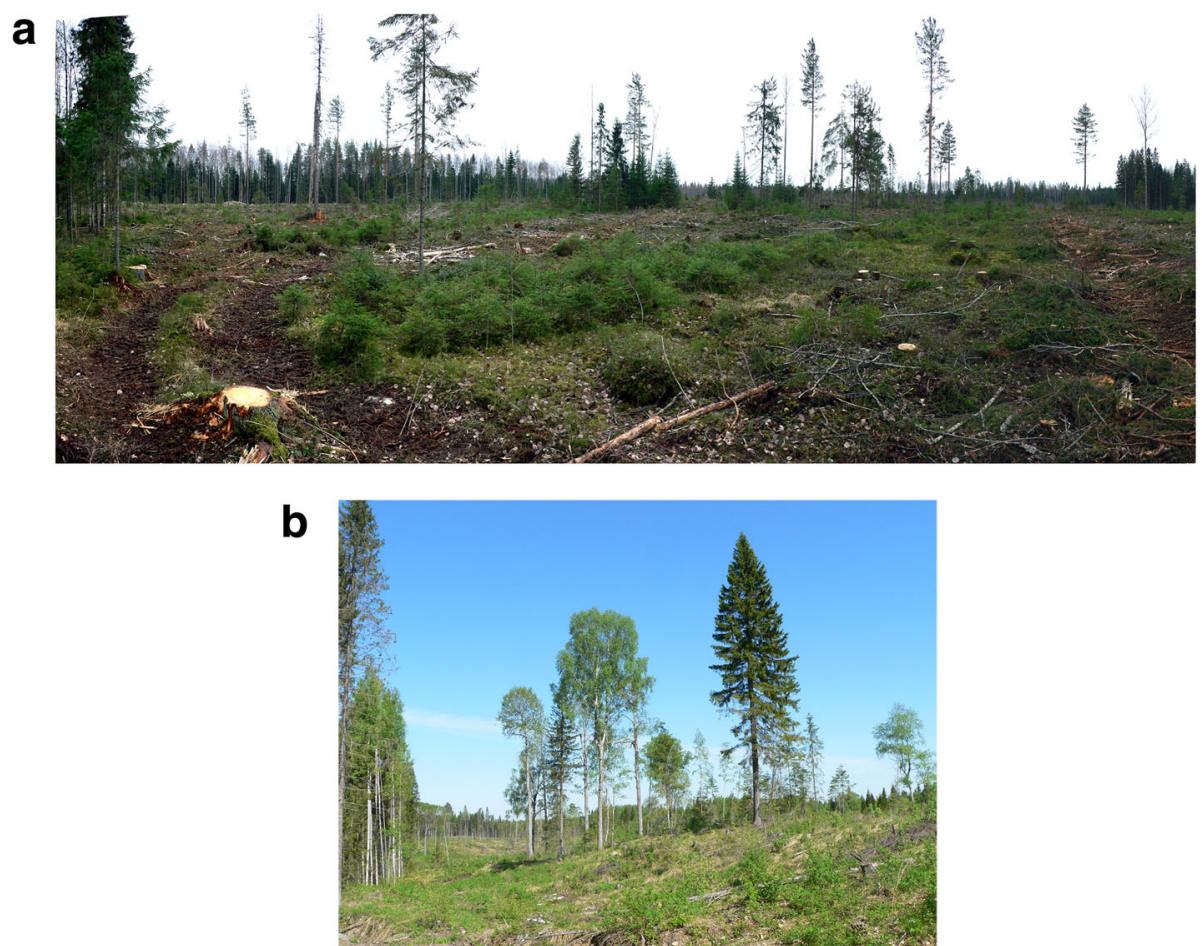

Fig. $\mathbf{6}$ a, b Examples of modern clear-cut areas with retained seed trees and seed tree groups, low-diameter trees, understory, CWD, and a key biotopes in the middle boreal forest in the Republic of Karelia. Photo: Sergey Sinkevich

Key biotopes preserved in managed forest landscapes since 1978 are aggregates of 0.1 up to 1000 ha. Additionally, promoted by forest certification, key biotopes and key elements (retention forest patches and individual structures, Table 1) with possible buffer zones around them are excluded from harvesting (Romanyuk et al. 2001; Pautov et al. 2007; Raj et al. 2008; Andersson et al. 2009a, b; Nikonov and Smirnov 2012; Markovsky and

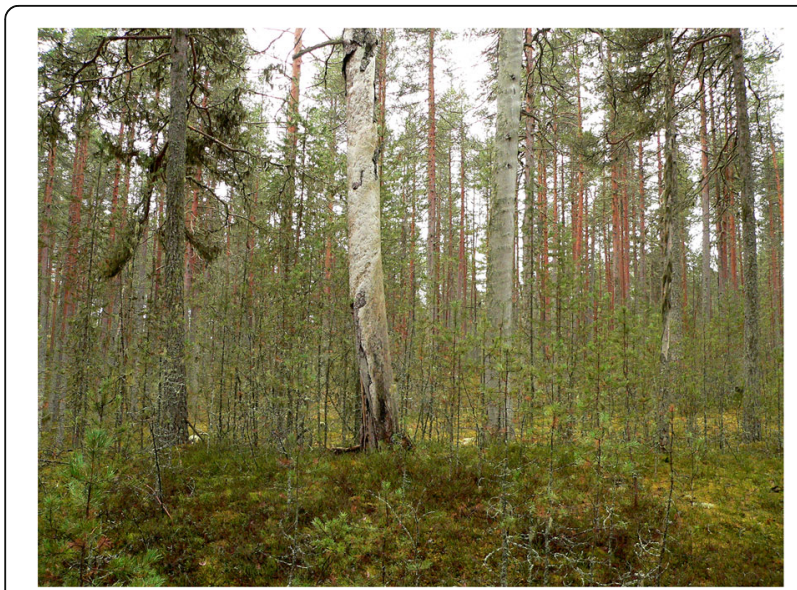

Fig. 7 Seed trees (snags on the photo) retained in clear felling and survived few felling rotations. Eastern shore of Lake Syamozero, southern boreal forest, the Republic of Karelia. Photo: Sergey Sinkevich
Iljina 2014; Moshnikov et al. 2019). Leaving retention tree patches and key elements in harvesting areas started from model forests in 2000 (Romanyuk et al. 2001; Elbakidze and Angelstam 2008; Elbakidze et al. 2010) and later become a common practice in NW Russia (Ilina et al. 2009, 2016, 2018).

The key biotopes and elements preserved in NW Russian harvesting areas are rather similar to woodland key habitats in Fennoscandian (Sweden, Finland, Norway) and Baltic (Latvia, Estonia, Lithuania) countries (Timonen et al. 2010). The main types include, for example, forest patches around peatlands, small lakes, and springs; uneven-aged forest patches; gaps after windthrows; regionally rare tree species; old trees; trees with bird nests and hollows; snags; high stumps, and large (e.g., in the Arkhangelsk region, more than $25 \mathrm{~cm}$ in diameter) downed deadwood of different decay classes (Table 1).

Quantitative estimates of past and present retention are largely missing. In the middle of the twentieth century, the level of retention from incomplete felling in NW Russia varied greatly: from 1 to $146 \mathrm{~m}^{3} \mathrm{ha}^{-1}$, or $1-83 \%$ of the growing stock (Sakhovets 1977). Within a harvesting area, $18-33 \%$ was left uncut on average, and the growing stock of an uncut patch averaged $30-40 \mathrm{~m}^{3} \mathrm{ha}^{-1}$ (Baranov 1954; Marjin 1957). There is no precise data on the amounts of seed trees retained in harvesting areas. However, the volume of seed trees per ha (Federal state 
Table 1 Types and levels of retention with examples of types of key biotopes and key elements retained in the harvesting areas in NW Russian forests

\begin{tabular}{|c|c|c|}
\hline Type of retention; amount or size & General characteristics and purpose & Time period \\
\hline Uncut patches; 0.001-30 ha & $\begin{array}{l}\text { Mainly deciduous and low-diameter or decaying } \\
\text { coniferous trees on paludified or unreachable } \\
\text { sites with a high amount of CWD. } \\
\text { "No economic value" }\end{array}$ & Since the 1910 s \\
\hline $\begin{array}{l}\text { Seed trees; } 20-25 \text { trees per ha in } \\
\text { groups of } 3-5 \text { trees }\end{array}$ & $\begin{array}{l}\text { Mainly pine and spruce, left to ensure natural } \\
\text { regeneration }\end{array}$ & Since the 1930s \\
\hline $\begin{array}{l}\text { Understory, low-diameter trees; all } \\
\text { possible viable seedlings }\end{array}$ & $\begin{array}{l}\text { Left to ensure natural regeneration and reach } \\
\text { the target stocking level }\end{array}$ & Since the 1930s \\
\hline Coarse woody debris & $\begin{array}{l}\text { Snags and logs of different sizes, tree species, } \\
\text { and decay classes. } \\
\text { "No economic value" }\end{array}$ & Since the 1930s \\
\hline $\begin{array}{l}\text { Key biotopes; the whole forest patch } \\
\text { is completely preserved; ca. } 0.1-100 \text { ha }\end{array}$ & $\begin{array}{l}\text { Paludified patches; ecotones between peatlands } \\
\text { and forests; forest "islands" in peatlands; forest } \\
\text { patches on rocky sites or steep slopes, cliffs, and } \\
\text { canyons; spruce-black alder and paludified spruce } \\
\text { forests, pine forests of herb-sphagnum type; patches } \\
\text { with uneven-aged structure and old trees; habitats } \\
\text { of red-listed species of different taxonomic groups; } \\
\text { places of capercaillie mating call }\end{array}$ & $\begin{array}{l}\text { Since } 1978 \text {, with more } \\
\text { types added afterwards }\end{array}$ \\
\hline $\begin{array}{l}\text { Buffer zones around key biotopes or } \\
\text { elements, 20-50 m; buffer zones around } \\
\text { trees with big nests, 300-500 m }\end{array}$ & $\begin{array}{l}\text { Buffer zones around ecotones between peatlands } \\
\text { and forests; forest buffers around small water bodies; } \\
\text { forests on steep slopes and cliffs and canyons; zones } \\
\text { around badger and fox burrows; zones around trees } \\
\text { with bird nests; forests around boulders of more } \\
\text { than } 6 \mathrm{~m}\end{array}$ & Since 2000 \\
\hline Key elements; completely preserved & $\begin{array}{l}\text { Trees of regionally rare species; red-listed tree species; } \\
\text { old and decaying trees; snags; high stumps from } \\
\text { naturally broken trees; trees with nests and hollows; } \\
\text { uprooted trees; logs of different decay classes }\end{array}$ & Since 2000 \\
\hline
\end{tabular}

Adopted from Romanyuk et al. (2001); Pautov et al. (2007); Raj et al. (2008); Andersson et al. (2009a); Yanitskaya (2010); Nikonov and Smirnov (2012); Markovsky and Iljina (2014); Methodological (2017); Moshnikov et al. (2019)

statistics 2019; Fedorchuk et al. 2005; Finnish forest statistics 2018; Forest Code 1923; Forest Code 2007; Forest regeneration in 2016, 2017) can be estimated, based on forest mensuration data by tree species (Tetioukhin et al. 2004), to be $15-25 \mathrm{~m}^{3} \mathrm{ha}^{-1}$ for spruce and pine respectively. The volumes of CWD in harvesting areas average $30 \mathrm{~m}^{3} \mathrm{ha}^{-1}$ (Galaktionov 2008). However, in some cases, they can exceed $100 \mathrm{~m}^{3} \mathrm{ha}^{-1}$ (Kapitsa et al. 2019).

Evidence on the amount of key biotopes and elements is scarce. According to the information provided by ten FSCcertified forest companies for the period 2005-2014, the area of key biotopes inside clear-cut areas varied from 1 to $13 \%$ with a mean value of $6 \%$ (Ilina and Rodionov 2017). However, most key biotopes are protected outside the areas planned to be harvested (Ilina and Rodionov 2017). For example, the area of key biotopes in harvesting areas in the Pskov model forest averages 10\% (Zagidullina, pers. com), whereas the total area of key biotopes comprises $23 \%$ of all Pskov model forest land (Bublichenko 2004). In the Pryazhinskoye and Kondopozhskoye forest management areas (lesnichestvo) in the Republic of Karelia, 12\% of the mature forest area are key biotopes (Sinkevich, unpublished).
Studies on the impact of VR on biodiversity and ecosystem functions are scarce in Russia. However, some studies have demonstrated the positive role of uncut forest patches for forest regeneration (Asoskov 1940; Kischenko, Vilikainen 1957; Marjin 1957; Melekhov 1966) and preserving forest microclimate and environment, preventing paludification, and consequently providing important ecosystem functions (Yaroshenko 2005). Uncut patches, together with seed tree groups and patches of understory left permanently in the harvesting areas, form a natural refuge for biodiversity in managed landscapes (Kravchenko 1999; Volkov et al. 2002; Kravchenko et al. 2004; Kryshen 2006; Gromtsev et al. 2010; Ivanter and Kurhinen 2016; Fadeeva and Kravchenko 2018).

\section{Gaps in knowledge and future perspectives of VR in Russia}

Information about forest resources and forestry practices in NW Russia is the most complete, compared to other parts of Russia. However, statistics of what has been actually left unharvested and where are still largely missing even in NW Russia. A systematic inventory reviewing 
the amounts, patterns, and quality of retention in spatiotemporal dynamics would provide more robust information of current forest structures in NW Russia. The long time period of clear felling, but with high retention levels, provides the unique possibility to evaluate the longterm impact of VR forestry on biodiversity and forest dynamics, since the species richness of different taxonomic groups changes with time following harvest (Fedrowitz et al. 2014). Information on retention practices and a magnitude of soil preparation after harvesting would improve the assessment of the role of Russian forestry in climate regulation (Pohjanmies et al. 2017) and provide a better understanding of the mechanisms of forest management impact on ecosystem resilience under climate change (Chapin et al. 2007; Millar et al. 2007).

Recently, increasing wood production according to the so-called Fennoscandian model of intensive forest management (Karjalainen et al. 2009; Karvinen et al. 2006, 2011) is being discussed in Russia. The concept of adaptive management for maximizing resilience and the sustainability of forests under climate change has been recommended as an alternative (Karpachevsky 2007; Nordberg et al., 2013; Chapin et al. 2007; Naumov et al. 2017). This concept suggests further development of selection felling practices and preserving key biotopes and elements in parallel with the research and monitoring of the results of their practical implementation. Its implementation, however, requires overcoming discrepancies between existing forestry regulations and sustainability (Karpachevsky 2007; Yanitskaya and Shmatkov 2009, Shmatkov, 2013a, b; Kulikova et al. 2017; Sinkevich et al. 2018) by taking into account diverse natural and socio-economic conditions across the country with varying legacies from past forestry activities (Shvarts, 2003; Shvidenko and Schepaschenko, 2011; Lukina et al. 2015; Naumov et al. 2017; Sinkevich et al. 2018) (Additional file 1).

\section{Conclusions}

Retention forestry in NW Russia has been practiced over a century for varying reasons. The biological legacies left in harvesting areas, either aggregated or dispersed, have emulated natural disturbance patterns and processes and created uneven-aged forests with diverse structures. Thus, the recommendations for sustainable forest management and ecological restoration developed recently in other Fennoscandian or other boreal regions have been applied in NW Russia already for over a hundred years.

Currently, Russian forest policy is at a decisive point in terms of its general direction. Ignoring natural and socio-cultural diversity across regions and concentrating only on maximizing wood production will lead to the risk of losing other ecosystem services. Future decisions concerning retention practices in NW Russian forestry are thus important to a global biodiversity and climate change mitigation.

\section{Additional file}

Additional file 1: References in the Russian language. (DOCX $27 \mathrm{~kb}$ )

\section{Abbreviations}

CWD: Coarse woody debris; NW: Northwestern; VR: Variable retention

\section{Acknowledgements}

We thank Vladimir Kharitonov, Sergey Moshnikov, Elena Moshkina, and Ivan Romashkin for providing expert opinions on some issues and for helping with relevant literature.

\section{Authors' contributions}

ES wrote the initial drafts of the manuscript with comments from SS, AK, and IV. ES, SS, AK, and IV together developed the ideas and framework for the manuscript. ES, SS, and AK went through the Russian language literature. All authors read and approved the final version of the manuscript.

\section{Funding}

The study was carried out in frames of the state order of the Forest Research Institute of the Karelian Research Centre, Russian Academy of Sciences.

\section{Availability of data and materials \\ All data generated or analyzed during this study are included in this published article.}

Ethics approval and consent to participate

Not applicable

\section{Consent for publication}

Not applicable

\section{Competing interests}

The authors declare that they have no competing interests.

\section{Author details}

${ }^{1}$ Forest Research Institute of the Karelian Research Centre of the Russian Academy of Sciences, Pushkinskaya str. 11, Petrozavodsk 185910, Russia. ${ }^{2}$ Saint-Petersburg State Forest Technical University, Institutsky str. 5, Saint Petersburg 194021, Russia. ${ }^{3}$ Natural Resources Institute, Finland (Luke), Latokartanonkaari 9, Fl-00790 Helsinki, Finland.

Received: 23 April 2019 Accepted: 25 June 2019

Published online: 29 July 2019

\section{References}

Aksenov D, Karpachevskiy M, Lloyd S, Jaroshenko A (1999) The last of the last: the old-growth forests of boreal Europe. Taiga Rescue Network Publ. http://old. forest.ru/eng/publications/last/lastlast.pdf

Aksenov D et al. (2000) Position of nongovernmental organizations on key criteria of sustainable forestry in Russia. http://old.forest.ru/eng/sustainable_ forestry/vision/pushkino.html

Ananyev VA, Sinkevich SM (2015) Recommendations for fellings in the protective forests in Karelia. Kar. Res. Centre Publ, Petrozavodsk, p 34 (in Russian)

Andersson L, Alekseeva NM, Kuznetsova ES (2009a) Survey of biologically valuable forests in the northwestern European Russia. The methods of revealing and mapping. Saint Petersburg, Pobeda Publ 1:238 (in Russian)

Andersson L, Alekseeva NM, Kuznetsova ES (2009b) Survey of biologically valuable forests in the northwestern European Russia. Guidebook for identification of species in the forest stand level of survey, vol 2. StP, Pobeda Publ, p 238 (in Russian)

Annual report on the state and use of forest resources in the Russian Federation. (2012) Moskow (in Russian) 
Asoskov Al (1940) Silvicultural role of uncut patches on the clear cuts and incomplete clear cuts. Proc Saint Petersburg State Forest Academy 58: 128-139

Bajtin AA, Logvinov IV, Stolyarov DP (1974) Forest inventory. Forest industry publ, Moskow (in Russian)

Baranov NI (1954) Incomplete clear felllings and their economic importance. Central For. Res. Inst. Publ, Leningrad (in Russian)

Bonh U, Gollub G, Hettwer C [Bearb.] (2000). Karte der natürlichen Vegetation Europas / Map of the Natural Vegetation of Europe. Maßstab / Scale 1:2.500. 000. Teil 2/ Part 2: Legende / Legend, 153 S.; Teil 3 / Part 3: Karten / Maps (9 Blätter/Sheets, Legendenblatt / LegendSheet, Übersichtskarte 1:10 Mio. / General Map 1:10 million). - Münster (Landwirtschaftsverlag)

Bonh U, Neuhäusl R, unter Mitarbeit von Gollub G, Hettwer C, Neuhäuslová Z, Shlüter H, Weber H. (2003). Karte der natürlichen Vegetation Europas/Map of the natural vegetation of Europe. Maßstab / Scale 1:2.500.000. Teil 1 / Part 1: Erläuterungsband / Explanatory Text, 655 S.; Teil 2/Part 2: Legende / Legend, 153 S.; Teil 3 / Part 3: Karten / Maps (9 Blätter / Sheets, Legendenblatt / Legend Sheet, Übersichtskarte 1:10 Mio. / General Map 1:10 million). Münster (Landwirtschaftsverlag)

Bublichenko YN (2004) Developing a system to estimate biodiversity under intensive forestry on the example of terrestrial vertebrates, $\mathrm{p} 172$ Doctoral Thesis

Bukvareva EN, Zamolodchikov DG (eds) (2016) Ecosystem services in Russia: prototype of a national report. Services from terrestrial ecosystems, p 1

Chapin FS, Danell K, Elmqvist T, Folke C, Fresco N (2007) Managing climate change impacts to enhance the resilience and sustainability of Fennoscandian forests. AMBIO 36(7):528-533

Chibisov GA, et al (2004) Forest thinnings in the European North. Arkhangelsk Technical University Press, Arkhangelsk (in Russian)

Davydov (1934) Estimation of modern methods for clearing of harvesting areas (1934). Lelingrad, Goslestekhizdat Publ.

Dekatov NE (1961) Measures for natural forest regeneration during mechanized timber harvesting. Goslesbumizdat publ., Moskow (in Russian)

Elbakidze M, Angelstam P (2008) Model forests in northwestern Russia: view from the outside. Sustain Forest Use 1(17):39-47 (in Russian)

Elbakidze M, Angelstam PK, Sandström C, Axelsson R (2010) Multi-stakeholder collaboration in Russian and Swedish model forest initiatives: adaptive governance toward sustainable forest management? Ecol Soc 15(2):14

Fadeeva MA, Kravchenko AV (2018) Lichens in the clear-cut areas in the southern Karelia. In: Fungal communities in forest ecosystems. Ed. by Storoghenko VG and Ruokolainen AV. Russian Academy of Sciences Publ, MoskowPetrozavodsk, 5:122-135 (in Russian)

Federal state statistics (2019) http://www.gks.ru/bgd/regl/B11_14p/lssWWW.exe/ Stg/d02/15-39.htm. Accessed 1 Jan 2019

Fedorchuk VN, Neshataev VY, Kuznetsova ML (2005) Forest ecosystems of the north-western regions of Russia: typology, dynamics, management features. Saint-Petersburg Publ. (in Russian)

Fedrowitz K, Koricheva J, Baker SC, Lindenmayer D, Palik B et al (2014) Can retention forestry help conserve biodiversity? A meta-analysis. J Appl Ecol 51:1669-1679

Finnish forest statistics (2018) Luke, p 189

Forest Code (1923) (in Russian)

Forest Code (2007) (in Russian)

Forest regeneration in 2016 (2017) Moskow, Rosstat. (in Russian)

Franklin JF (1989) Towards a new forestry. Am For 95:37-44

Galaktionov (2008) Logging slash on harvesting areas. Proceedings of the Petrozavodsk State University Vol. 1 (90): 131-139 (in Russian).

Gauthier S, Bernier P, Kuuluvainen T, Shvidenko AZ, Schepaschenko DG (2015) Boreal forest health and global change. Science 349:819-822

Gromtsev AN, Kravchenko AV, Kurhinen YP, Sazonov SV (2010) Dynamics of forest communities, flora and fauna in the European taiga under natural conditions and after anthropogenic influence: an attempt of research and generalization. Proc Karelian Res Cent Russ Acad Sci 1:16-33 (in Russian)

Gromtsev AN, Levina MS, Presnukhin YV (2018) Protected areas in the Northern Europe: present state and a comparative assessment. Proc Karelian Res Cent Russ Acad Sci 1:81-88 (in Russian)

Gustafsson L, Baker SC, Bauhus J, Beese WJ, Brodie A, Kouki J, Lindenmayer DB, Lõhmus A, Martınez -Pastur G, Messier C, Neyland M, Palik B, SverdrupThygeson A, Volney VJA, Wayne A, Franklin JF (2012) Retention forestry to maintain multifunctional forests: a world perspective. Bioscience 62(7): 633-645
Hautala H, Jalonen J, Laaka-Lindberg S, Vanha-Majamaa I (2004) Impacts of retention felling on coarse woody debris (CWD) in mature boreal spruce forests in Finland. Biodivers Conserv 13:1541-1554

Ilina O, Karpachevsky M, Yanitskaya T (2009) The regulatory framework and practical recommendations for preserving biodiversity during timber harvesting. WWF, Moskow (in Russian)

Ilina O, Pilipenko E, Rodionov AO (2018) Comparative evaluation of biodiversity conservation by forest companies in northwestern Russia. Sustain For Use 53(1):39-45 (in Russian)

Ilina O, Rodionov A O (2017) The ways to preserve forest environment and mosaics of forest landscapes during $\mathrm{h}$ timber harvesting. LesPromlnform https://lesprominform.ru/jarticles.html?id=4788 (in Russian)

Ilina OV, Pilipenko EA, Rodionov AV (2016) Evaluation of biodiversity conservation during timber harvesting at logging enterprises of the Arkhangelsk region and the Republic of Karelia. Resour Technol 13(1):40-63

Ivanov AM, Shutov W, Petukhov IN, Yuferov MA (2009) Quality and characteristics of wood left on harvesting areas. Modern problems of forest sector, vol 24 , pp 27-29 (in Russian)

Ivanter EV, Kurhinen YP (2016) Impact of commercial forest logging on the boreal fauna communities (small mammals of the Eastern Fennoscandia as an example). Bull Russ Acad Sci Biol Ser 4:412-421 (in Russian)

Kapitsa EA, Shorohova EV, Romashkin IV, Galibina NA, Nikerova KM, Kazartsev IA (2019) Decomposition of bark in logging slash after clearcuts in middle boreal forests. Russ For Sci (1):38-48 (in Russian)

Karjalainen T, Leinonen T, Gerasimov Y, Husso M, Karvinen S (2009) Intensification of forest management and improvement of wood harvesting in Northwest Russia. Working Papers of the Finnish Forest Research Institute 110:151

Karpachevsky M (2007) Legislative tools for biodiversity conservation during forest fellings. Sustain For Use 13(1):18-23

Karvinen S, Gerasimov Y, Välkky E, Dobrovolsky A (2011) Northwest Russian forest sector in a nutshell. Metla publ p 139

Karvinen S, Välkky E, Torniainen T, Gerasimov Y (2006) Northwest Russian forestry in a nutshell. Working Papers of the Finnish Forest Research Institute 30:98

Kischenko TI, Vilikainen MI (1957) Seed tree groups in clear-cut areas in spruce forests. Proc Karelian Branch Rus Acad Sci 7:69-96 (in Russian)

Knize A, Romanjuk B (2004) About two points of view on the Russian forest and forestry. Sustain For Use 5(3):2-7 (in Russian)

Kobyakov K, Lepeshkin E, Titova S (2013) Protective forests: can we protect them? Sustain For Use 34(1):34-44 (in Russian)

Kozlov DV (2017) Legal regulation of forests in the Soviet period. Matters Russ Int Law 7(2B):271-278

Kozubov GM, Taskaev Al (2000) Forestry and forest resources in Komi Republic, p 512 (in Russian)

Kravchenko AV (1999) The role of uncut forest patches in preserving biodiversity in boreal forests after commercial harvesting. In: Biological basis for study, use and preserve animals, plants and soils in the eastern Fennoscandia, vol 6-10. Proc. Int. Conf, Petrozavodsk, pp 190-191 (in Russian)

Kravchenko AV, Gnatyuk EP, Kryshen AM (2004) Anthropogenic transformation of flora in the regions with intensive forest use. In: Anthropogenic transformation of European boreal forest ecosystems: ecological, resource and economic aspects. Proc. Int. Conf. Petrozavodsk, 23-25 of Dec. pp. 82-93. (in Russian)

Kryshen AM (2006) Plant communities on the harvesting areas in Karelia. Nauka publ, Moskow (in Russian)

Kulikova E, Ivannikova T, Shmatkov N (2017) The conference "sustainable forest use: regulations, management, problems and solutions". Sustain For Use 49(1):2-14 (in Russian)

Lazdinis M, Angelstam P (2005) Functionality of riparian forest ecotones in the context of former Soviet Union and Swedish forest management histories. For Policy Econ 7(3):321-332

Leman M, Kobyakov A, Vinnikov A (2018) Protective forests and conservation of water biological resources. Sustain For Use 53(1):2-10 (in Russian)

Lindenmayer DB, Franklin JF, Lõhmus A, Baker SC, Bauhus J, Beese W, Brodie A Kiehl B, Kouki J, Martínez Pastur G, Messier C, Neyland M, Palik B, SverdrupThygeson A, Volney J, Wayne A, Gustafsson L (2012) A major shift to the retention approach for forestry can help resolve some global forest sustainability issues. Conserv Lett 5:421-431

Lukina NV, Isaev AS, Kryshen AM, Onuchin AA, Sirin AA, Gagarin YN, Bartalev SA (2015) Priorities in the development of forest science as a basis for sustainable forest management. Russ For Sci 4:243-254 (in Russian) 
Marjin EM (1957) Silvicultural role of uncut forest patches left on the large-scale clear-cut areas in Karelia. Proc Karelian Branch Russ Acad Sci 7:26-45 (in Russian)

Markovsky AV, Iljina OV (2014) Methodological recommendations for preserving biological diversity during timber harvesting in the Vologda region. WWF. (in Russian)

Melekhov IS (1966) Final fellings, 2nd edn. Forest Industry publ, Moskow, p 374 (in Russian)

Melnikov DV (2011) Federal regions in Russia: economic aspect. Bul Tomsk State Univ 3(15):156-170 (in Russian)

Methodological (2017) Methodological recommendations for preserving biodiversity during timber harvesting in the Arkhangelsk region. (in Russian)

Millar Cl, Stephenson NL, Stephens SL (2007) Climate change and forests of the future: managing in the face of uncertainty. Ecol Appl 17(8):2145-2151

Moshnikov SA (ed) (2019) The list of key habitats and buffer zones set aside in timber harvesting in the Republic of Karelia. Scientific report of the Forest Research Institute of the Russian Academy of Sciences. Petrozavodsk.

National (2003) National report of Russian Federation on the criteria and indicators of conservation and sustainable forest management in the temperate and boreal forests (Montreal process, 2003) (in Russian)

Naumov V, Angelstam P, Elbakidze M (2017) Satisfying rival forestry objectives in the Komi Republic: effects of Russian zoning policy change on wood production and riparian forest conservation. Can J For Res 47:1339-1349

Nikolayuk VA, Sinitsyn SG, Semenchenko NN (1977) Use of forest resources. Forest Industry Publ, Moskow, p 240 (in Russian)

Nikonov MV, Smirnov IA (2012) Practical recommendations for timber harvesting during the transition to sustainable forest use and management in the Novgorod region. Novgorod State Univ, Velikiy Novgorod (in Russian)

Nordberg M, Angelstam P, Elbakidze M, Axelsson R (2013) From logging frontier towards sustainable forest management: experiences from boreal regions of NorthWest Russia and North Sweden. Scand J For Res 28(8):797-810

Pautov YA, Zasukhin DP, Klochikhin AN, Pautov SY, Poroshin EA (2007) FSC certification in Russia: practical solutions. Silver Taiga Publ, Syktyvkar (in Russian)

Pohjanmies T, Triviño M, Le Tortorec E, Mazziotta A, Snäll T, Mönkkönenet M (2017) Impacts of forestry on boreal forests: an ecosystem services perspective. Ambio 46:743-755

Rabinowitsch-Jokinen R, Vanha-Majamaa I (2010) Immediate effects of logging, mounding and removal of logging residues and stumps on coarse woody debris in managed boreal Norway spruce stands. Silva Fennica 44(1):51-62

Raj EA, Torkhov SV, Burova NV (2008) Key biotopes in the forest ecosystems of Arkhangelsk region and recommendations for their conservation. WWF Arkhangelsk (in Russian)

Redko Gl (1981) History of forestry in Russia. Moskow State Forest Univ. Publ, Leningrad (in Russian)

Regional forest plans $(2017,2018)$. a. Forest plan of the Arkhangelsk region, RF for the period of 2018-2028. b. Forest plan of the Vologda region for the period of 2018-2027. c. Forest plan of the Komi Republic for the period of 2018-2027. d. Forest plan of the Leningrad region for the period of 20192028. e. Forest plan of the Murmansk region for the period of 2009-2018. $f$ Forest plan of the Novgorod region for the period of 2019-2028. g. Forest plan of the Pskov region for the period of 2019-2028. h. Forest plan of the Republic of Karelia for the period of 2019-2028

Regulations for forest regeneration (2016b) (in Russian)

Regulations for thinnings in the forests (2017) (in Russian)

Regulations for timber harvesting (2016a) (in Russian)

Romanyuk BD, Zagidullina AT, Knize AA (2001) Planning forestry on a nature conservation basic WWF, Pskov model forest. (in Russian)

Scott RE, Neyland MG, Baker SC (2019) Variable retention in Tasmania, Australia: trends over 16 years of monitoring and adaptive management. Ecological Processes 8:23.

Sakhovets VI (1977) Silvicultural characteristics of scattered forests for commercial harvesting in the southern Karelia. Karelian Branch of the Russian Academy of Sciences, Petrozavodsk, pp 136-140 (in Russian)

Shmatkov N (2013a) The strategy for developing forestry and nature conservation regulations for the middle boreal forests aiming at sustainable forestry. Materials from round table, 18.03.2013. WWF. (in Russian)

Shmatkov N (2013b) Intensive sustainable forestry: barriers and perspectives for development. Moskow, WWF (in Russian)
Shvarts EA (2003) Forestry, economic development and biodiversity: rejecting myths of the past. Sustain For Use 2:2-7 (in Russian)

Shvidenko A, Schepaschenko D (2011) What do we know about Russian forests today? For Invent Forest Plan 1-2(45-46):153-172 (in Russian)

Shvidenko A, Shchepashchenko DG, McCallum I, Nilsson S (2007) Russian forests and forestry. IIASA and the Russian Academy of Sciences, Laxenburg (CD-ROM)

Sinkevich SM, Sokolov Al, Ananyev VA, Kryshen AM (2018) On the regulatory framework for intensification of forestry. Siberian For J 4:66-75 (in Russian)

Sobolev NA, Shvarts EA, Kreindlin ML, Mokievsky VO, Zubakin VA (1995) Russia's protected areas: base survey and identification of development problems. Biodivers Conserv 4(9):964-983

Sokolov Al (2006) Forest regeneration of harvesting areas in northwestern Russia. KarSC RAS Publ., Petrozavodsk, p 215 (in Russian)

Solntsev ZY (1950) Cuttings and regeneration in the forests of the III category in the northern and northwestern regions of the European part of the USSR. In: Proc. Sci. Conf. On the Forestry in the Karelian Finnish Republic, pp 56-71 in Russian

Teplyakov VK, Kuzmichev YP, Baumgartner DM, Everett RL (1998) A history of Russian forestry and its leaders. DIANE Publ, p 77

Tetioukhin SV, Minayev VN, Bogomolova LP (2004) Forest Mensuration and Inventory: Reference Book for the North-Western Russia. Saint-Petersburg Forest Technical Academy Publishers, St Petersburg, 360 pp (in Russian).

The Act on the allotment of areas for harvesting in the state forests of the USSR and on the logging fund in 1943. (1943)

The Russian Federation forest sector outlook study to 2030 (2012). FAO, 84 p

Tikhonov AS, Zyabcnenko SS (1990) Theory and practice of forest fellings. (in Russian)

Timonen J, Siitonen J, Gustafsson L, Kotiaho JS, Stokland JN, Sverdrup-Thygeson A (2010) Woodland key habitats in northern Europe: concepts, inventory and protection. Scand J For Res 25:309-324

Tkachenko ME (1931) Clearing of harvesting areas. Moskow, Selkhozizdat Publ. (in Russian).

Tkachenko ME (1955) Forestry. Leningrad, Goslesbumizdat Publ (in Russian)

Valentik IY (1950) State and objectives of forestry in the Karelian-Finnish Republic. Proc. Sci. Conf. On the Forestry in the Karelian Finnish Republic, pp 7-25 (in Russian)

Vanha-Majamaa I, Jalonen J (2001) Green tree retention in Fennoscandian forestry. Scand J For Res 16(S3):79-90

Volkov AD, Belonogova TV, Kurhinen YP, Sazonov SV, Sinkevich SM, Shubin VI (2002) The biodiversity factor and complex productivity of forest ecosystems in the forests of the northwestern European Russia. KarSC RAS Publ, Petrozavodsk (in Russian)

Yanitskaya T (2010) Practice of biodiversity conservation during forest harvesting. Sustain For Use 1:22-27 (in Russian)

Yanitskaya T, Shmatkov N (2009) Joint opinion of public environmental organisations and Russian forest business on the improvement of law related to sustainable forest management. Sustain For Use 3(22):42-44

Yaroshenko AY (2005) About leaving low-value deciduous trees on clear-cut areas. For Bull 28 http://old.forest.ru/rus/bulletin/28/9.html

\section{Publisher's Note}

Springer Nature remains neutral with regard to jurisdictional claims in published maps and institutional affiliations. 